\title{
Erratum to: A review of the direct and indirect effects of neonicotinoids and fipronil on vertebrate wildlife
}

\author{
David Gibbons $^{1} \cdot$ Christy Morrissey $^{2,3} \cdot$ Pierre Mineau $^{4}$
}

Published online: 10 November 2015

(C) Springer-Verlag Berlin Heidelberg 2015

Erratum to: Environ Sci Pollut Res (2015) 22:103-118

DOI 10.1007/s11356-014-3180-5

On p109, in Table 2, both concentrations of $1 \mathrm{mg} / \mathrm{kg} /$ day referring to the Japanese quail should be of clothianidin, rather than imidacloprid.

In addition, the following text on p110 should be removed: While imidacloprid is highly toxic to Japanese quail, with an LD50 of $31 \mathrm{mg} / \mathrm{kg}$, chronic daily doses of only $1 \mathrm{mg} / \mathrm{kg} / \mathrm{day}$ can lead to testicular anomalies, DNA damage in males, and reductions in embryo size when those males are mated with control females.

And replaced with:

While clothianidin is moderately toxic to Japanese quail, with an LD50 of $423 \mathrm{mg} / \mathrm{kg}$, chronic daily doses of only $1 \mathrm{mg} / \mathrm{kg} /$ day can lead to testicular anomalies, DNA damage in males, and reductions in embryo size when those males are mated with control females.

The online version of the original article can be found at http://dx.doi.org/ 10.1007/s11356-014-3180-5.

David Gibbons

david.gibbons@rspb.org.uk

1 RSPB Centre for Conservation Science, RSPB, The Lodge, Sandy, Bedfordshire SG19 2DL, UK

2 Department of Biology, University of Saskatchewan, 112 Science Place, Saskatoon, Saskatchewan S7N 5E2, Canada

3 School of Environment and Sustainability, University of Saskatchewan, 117 Science Place, Saskatoon, Saskatchewan S7N 5E2, Canada

4 Pierre Mineau Consulting, 124 Creekside Drive, Salt Spring Island, BC V8K 2E4, Canada 